\title{
Toleransi Antar Umat Beragama Di Kecamatan Prambanan Kabupaten Klaten
}

\section{Kharina Rahmanika ${ }^{1}$, Danick Wahyu Pratiwi ${ }^{2}$, Arfan Pajar Santoso $^{3}$, Novry Berlyanda.HS ${ }^{4}$, Eny Susilowati ${ }^{5}$, ${ }^{6}$ Farizky Yunarta}

Universitas Muhammadiyah Surakarta

E-Mail: ${ }^{1}$ kharinarahmanika3@gmail.com,

${ }^{2}$ Danickpratiwi@gmail.com, ${ }^{3}$ a610160031@ @ student.ums.ac.id,

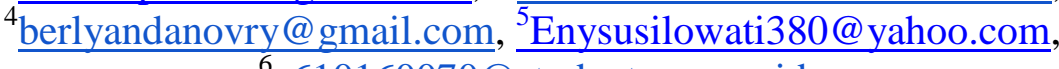

6610160070@student.ums.ac.id

\begin{abstract}
Religious tolerance in Indonesia is still much has issues indicate that the understanding of the people's harmony between religious. The purpose of this research is describe level of freedom, harmony and religious tolerance. This research method using quantitative descriptive method, the population in this research is the entire community of 16 buildings persil village in sub-district of Prambanan, Klaten Regency. A population totalling 20,943 building later used the technique of sampling and resulting 2,235 respondents research. The results showed that Concord, from every religions mutually open mind and accept the existence of other religions. The presence of the religious diversity that exists in Prambanan, does not make the relationship of interaction between the communities in Prambanan district become porous and rigid, it makes its own beauty that can be seen from the indicator of freedom religion as much as $84.5 \%$ of respondents strongly agree and agree, namely, $79.5 \%$ of respondents live in the strongly agree, agree, as much $40 \%$ of respondents strongly disagree with the existence of conflicts between believers and the rest declared neutral. The results showed that the public have a good harmony and tolerance and does not want have a conflict in society.
\end{abstract}

Keywords: Religious Harmony, Tolerance, Conflict 
120 Kharina, Danick, Arfan, Novry, Eny \& Farizky: Toleransi Antar...

\begin{abstract}
Abstrak
Toleransi antar umat beragama di Indonesia masih banyak menyisakan masalah mengindikasikan bahwa pemahaman masyarakat tentang kerukunan antar umat beragama.Tujuan dari penelitian ini adalah mendiskripsikan tingkat kebebasan, kerukunan dan toleransi beragama. Metode penelitian ini menggunakan metode deskriptif kuantitatif, populasi dalam penelitian ini adalah seluruh persil bangunan masyarakat dari 16 desa di Kecamatan Prambanan, Kabupaten Klaten. Populasi berjumlah 20.943 bangunan kemudian digunakan teknik sampling dan menghasilkan 2.235 responden penelitian. Hasil penelitian menunjukkan bahwa kerukunan, dari setiap pemeluk agama saling terbuka dan menerima keberadaan dari agama lain. Adanya keanekaragaman beragama yang ada di Kecamatan Prambanan, tidak membuat hubungan interaksi antara masyarakat di Kecamatan Prambanan menjadi renggang dan kaku, hal tersebut membuat keindahan tersendiri yang dapat dilihat dari indikator kebebasan beragama sebanyak 84,5\% responden sangat setuju dan setuju, kerukunan yaitu $79,5 \%$ responden yang sangat setuju, sebanyak $40 \%$ responden sangat tidak setuju dengan adanya konflik antar umat beragama dan sisanya menyatakan netral. Hasil tersebut menunjukkan bahwa masyarakat memiliki toleransi dan kerukunan yang baik serta tidak menginginkan adanya konflik dalam masyarakat.
\end{abstract}

Keywords: Toleransi, Kerukunan Umat Beragama, Konflik

\title{
A. Pendahuluan
}

\section{Latar Belakang}

Indonesia merupakan bangsa yang paling banyak mempunyai keragaman, baik hayati, budaya, adat, bahasa, suku maupun agama.Terdaat 5 agama di Indonesia yaitu islam, Kristen, Hindu, Budha dan Konghucu hal ini mengindentifikasikan bahwa pemahaman masyarakat tentang kerukunan serta toleransi antar umat beragama perlu di 
terapkan jika tidak akan banyak konflik-konflik bermunculan. ${ }^{1}$ Banyaknya konflik yang melibatkan agama sebagai pemicunya menuntut adanya perhatian yang serius untuk mengambil langkah-langkah yang antisipatif demi damainya kehidupan umat beragama di Indonesia pada masamasa mendatang. Jika hal ini diabaikan, dikhawatirkan akan muncul masalah yang lebih berat dalam rangka pembangunan bangsa dan negara di bidang politik, ekonomi, keamanan, budaya, dan bidang-bidang lainnya. ${ }^{2}$

Adanya perubahan kondisi seperti sekarang ini seharusnya meningkatkan kesadaran masyarakat kita akan arti penting persatuan dan kesatuan. Akan tetapi kenyataan yang terjadi justru sebaliknya reformasi membawa dampak kebebasan yang kurang baik. Hal ini akan sangat berbahaya ketika terjadi di tengah-tengah bangsa yang tingkat heterogenitasnya cukup tinggi seperti Indonesia. Rakyat Indonesia mencita- citakan suatu masyarakat yang cinta damai dan diikat oleh rasa persatuan nasional untuk membangun sebuah negara yang majemuk. Persatuan ini tidak lagi membeda-bedakan agama, etnis, golongan, kepentingan, dan yang sejenisnya. ${ }^{3}$

Kajian tentang hubungan antar umat beragama dan antar etnis sekarang ini memasuki tantangan baru dan semakin menarik untuk diteliti dan di diskusikan. Hal ini disebabkan oleh munculnya konflik-konflik bernuansa SARA (Suku, Ras, Agama dan Antar Golongan) dan perubahan dinamika

${ }^{1}$ Muhammad : BUKHORI, BAIDI;. Toleransi Terhadap Umat Kristiani Ditinjau Dari Fundamentalisme Agama Dan Kontrol Diri . Laporan Penelitian Individual, Semarang: IAIN Walisongo, 2012

2 Hendropuspito : Nisa, Anita Khusnun. "Kajian Kritis Tentang Toleransi Beragama Dalam Islam." AL-Hikmah: Jurnal Studi Agama-Agama, 2016

3Thorik, Ahmad;. "Masyarakat Madani." Portal Garuda. 2014. portalgaruda.org ( diakses Mei 30, 2018). 
122 Kharina, Danick, Arfan, Novry, Eny \& Farizky: Toleransi Antar...

hubungan sosial dan keagamaan yang terjadi dilapangan. Berbagai peristiwa yang sempat menggejolak disebagian wilayah Indonesia beberapa tahun terakhir menunjukan indikasi bahwa telah terjadi pergeseran hubungan antar agama dan antar etnis di negeri ini. Konflik agama terutama merupakan ungkapan sengit atas kesalahan-kesalahan yang menggunakan agama sebagai basis identitas kelompok.

Kerusuhan-kerusuhan yang terjadi di Indonesia adalah tanggapan terhadap ketimpangan sosial ekonomi, penggusuran ekonomi oleh pendatang, legitimasi politik yang menurun, dan pandangan mengenai ancaman terhadap identitas kelompok. Dalam sejumlah kasus, kerusuhan itu melibatkan keluhan yang lebih langsung atas hak-hak praktik beragama. Penggunaan identitas agama menuntut penjelasan melampaui berbagai sebab kekerasan yang bersifat langsung. ${ }^{4}$

Setiap pemeluk agama umumnya meyakini bahwa agama yang dianutnya adalah jalan yang paling benar (baginya). Umat beragama sendiri, meyakini dengan teks dan kitab suci yang sama. Karena berbagai faktor, terdapat penafsiran dan pemahaman yang juga bisa berbeda. Perbedaan interpretasi terhadap teks-teks suci tersebut mengakibatkan timbulnya kelompok-kelompok keagamaan yang berbeda diantara para penganut agama yang sama tersebut. Semua itu tentu tidak masalah sejauh keyakinan dan pemahaman tersebut tidak diikuti dengan prasangka bahwa diluar agama yang dipeluk oleh kelompoknya dan diluar paham yang dia anut adalah sesuatu yang salah dan sesat. Sayangnya, di antara problem yang paling dekat dan menghadang dalam mewujudkan

${ }^{4}$ Yusuf, Angga Syaripudin;. KERUKUNAN UMAT BERAGAMA ANTARA ISLAM, KRISTEN DAN SUNDA WIWITAN. Skripsi, Jakarta: Universitas Islam Negeri Syarif Hidayatullah Jakarta, 2014. 
masyarakat pluralis saat ini antara lain adalah berkembangnya faham keagamaan eksklusif yang secara esensi memandang bahwa hanya agamanya saja yang paling benar sedangkan yang lain salah belaka. Karenanya demi tegaknya kebenaran (versi mereka) semua yang salah itu harus hilangkan, kalau perlu dengan kekerasan. Kelompok eksklusif semacam inilah yang cenderung menampilkan agama dalam wadah yang keras dan radikal biasanya ekstrim. Kelompok semacam ini terdapat pada setiap agama. Hanya saja, baik intensitas ekstrimitas maupun besar kecilnya perkembangan gerakan tersebut sangat tergantung pada kesempatan yang ada atau yang dapat mereka raih. Syukurlah bahwa secara keseluruhan kelompok seperti ini kecil jumlahnya, tetapi seringkali suara dan gemanya lebih nyaring dari yang lain sehingga dapat berdampak pada citra keseluruhan kelompok agama yang bersangkutan dan bagi umat beragama diluarnya. Sebaliknya, kelompok arus utama (the main stream) dari berbagai kelompok agama yang ada pada umumnya adalah moderat, namun biasanya suaranya kalah nyaring dibanding kelompok eksklusif. Keberadaan berbagai kelompok eksklusif dan ekstrem tersebut tak urung telah menyulut terjadinya sejumlah konflik baik internal dalam satu agama maupun eksternal antar agama, walau agama secara esensial mengajarkan hidup rukun dan damai baik antar sesama maupun antar sesama dengan lingkungan. ${ }^{5}$

Gambaran realitas di atas, dan berangkat dari adanya salah satu keunikan dalam realitas yang cukup menarik, bahwa ada satu daerah di Jawa yaitu Jawa Tengah, yang lebih tepatnya di daerah Kecamatan Prambanan, Kabupaten Klaten yang masyarakatnya rukun dan harmonis, yang daerah

5 Muhaimin AG : Yusuf, Angga Syaripudin;. KERUKUNAN UMAT BERAGAMA ANTARA ISLAM, KRISTEN DAN SUNDA WIWITAN. Skripsi, Jakarta: Universitas Islam Negeri Syarif Hidayatullah Jakarta, 2014.

Fikri, Vol. 3, No. 1, Juni 2018 
terdapat peninggalan budaya agama Hindu terbesar di dunia yang berada dalam komposisi masyarakat yang dari sisi agama heterogen, yaitu agama Islam (agama mayoritas). Akan tetapi dalam kehidupan sosialnya tetap berdampingan sejak lama tanpa terjadi konflik sampai saat ini.

Negara Indonesia adalah salah satu negara multikultur terbesar di dunia, hal ini dapat terlihat dari kondisi sosiokultural maupun geografis Indonesia yang begitu kompleks, beragam, dan luas. Indonesia terdiri atas sejumlah besar kelompok etnis, budaya, agama, dan lain-lain yang masingmasing plural (jamak) dan sekaligus juga heterogen aneka ragam. ${ }^{6}$ Sebagai negara yang plural dan heterogen, Indonesia memiliki potensi kekayaan multi etnis, multi kultur, dan multi agama yang kesemuanya merupakan potensi untuk membangun negara multikultur yang besar "multicultural nationstate". Keragaman masyarakat multikultural sebagai kekayaan bangsa di sisi lain sangat rawan memicu konflik dan perpecahan. Sebagaimana yang dikemukakan oleh Nasikun bahwa kemajemukan masyarakat Indonesia paling tidak dapat dilihat dari dua cirinya yang unik, pertama secara horizontal, ia ditandai oleh kenyataan adanya kesatuan-kesatuan sosial berdasarkan perbedaan suku bangsa, agama, adat, serta perbedaan kedaerahan, dan kedua secara vertikal ditandai oleh adanya perbedaan-perbedaan vertikal antara lapisan atas dan lapisan bawah yang cukup tajam. ${ }^{7}$

6 Kusumohamidjojo: Lestari, Gina; Bhineka Tunggal Ika: Khasanah Multikultural Indonesia di Tengah kehidupan Sara. Jurnal Pendidikan Pancasila dan Kewarganegaraan 2015.

7 Nasikun: Lestari, Gina;. Bhineka Tunggal Ika: Khasanah Multikultural Indonesia di Tengah kehidupan Sara. Jurnal Pendidikan Pancasila dan Kewarganegaraan 2015 


\section{Rumusan Masalah}

Bagaimana tingkat kerukunan, kebebasan dan konflik beragama di Kecamatan Prambanan Kabupaten Klaten ?

\section{Metode Penelitian}

Penelitian ini menggunakan jenis penelitian deskriptif kuantitatif. Metode penelitian kuantitatif dikemukakan oleh Sugiyono (2017) yaitu,"metode ini disebut sebagai metode positivistic karena berlandaskan pada filsafat positivisme. Metode ini sebagai metode ilmiah karena telah memenuhi kaidah-kaidah ilmiah yaitu konkrit/empiris, obyektif, terukur, rasional, dan sistematis. Metode ini disebut metode kuantitatif karena data penelitian berupa angka-angka dan analisis menggunakan statistik".

Penelitian deskriptif kuantitatif merupakan data yang diperoleh dari sampel populasi yang digunakan dengan cara analisis sesuai dengan statistik yang digunakan. Penelitian deskriptif ini untuk mendapatkan bagaimana gambaran mengenai toleransi antar umat beragama yang ada di seluruh desa di Kecamatan Prambanan.

Lokasi penelitian bertempat di daerah di Kecamatan Prambanan Kabupaten Klaten Jawa Tengah Waktu pelaksanaan penelitian ini dilaksanakan mulai bulan februari pembuatan sampai dengan bulan mei Letak Kecamatan Prambanan dapat dilihat pada peta persebaran tempat ibadah Kecamatan Prambanan berikut:

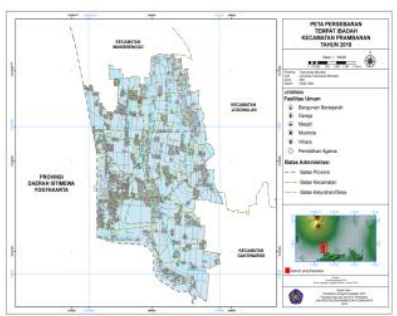

Gambar 1. Peta Persebaran Tempat Ibadah 
Populasi dalam penelitian ini adalah seluruh persil bangunan pemukiman masyarakat dari 16 desa di Kecamatan Prambanan yang didapatkan berdasarkan citra dan survei langsung dilapangan. Populasi pada penelitian ini sejumlah 20.943 bangunan pemukiman.

Teknik yang digunakan dalam penelitian ini adalah teknik wawancara dengan instrumen penelitian berupa angket/kuesioner. Penelitian ini dilaksanakan secara langsung terjun ke lapangan untuk mendapatkan data yang diperlukan. Penelitian ini menggunakan metode penelitian deskriptif kuantitatif yang melibatkan perhitungan angka atau kuantitas.

Hasil analisis data merupakan persentase yang menunjukkan hasil toleransi antar umat beragama di Kecmatan Prambanan. Penelitian ini mempelajari tentang masalah-masalah yang ada didalam masyarakat dan juga tata cara yang digunakan dalam masyarakat seta dalam situasi tertentu. Penelitian deskriptif merupakan jenis metode yang menggambarkan suatu objek dan subjek yang sedang diteliti tanpa adanya rekayasa. Termasuk mengenai hubungan tentang kegiatan, pandangan, sikap dan proses-proses yang berpengaruh dalam suatu fenomena yang terjadi.

\section{B. Kajian Teoritik}

\section{Toleransi}

Toleransi secara Bahasa berasal dari Bahasa Inggris "Tolerance" yang berarti membiarkan. Bahasa Indonesia diartikan sebagai sifat atau sikap toleran, mendiamkan membiarkan. Bahasa Arab kata toleransi (mengutip kamus Al-munawir disebut dengan istilah tasamuh yang berarti sikap membiarkan atau lapang dada) Badawi mengatakan, tasamuh (toleransi) adalah pendirian atau sikap yang termanifestasikan pada kesediaan untuk menerima berbagai 
pandangan dan pendirian yang beraneka ragam meskipun tidak sependapat dengannya

Toleransi dalam beragama bukan berarti bebas mengikuti ibadah dan ritualitas semua agama. Akan tetapi, toleransi beragama harus dipahami sebagai bentuk pengakuan akan adanya agama-agama lain selain agama sendiri dengan segala bentuk sistem, dan tata cara peribadatannya serta memberikan kebebasan untuk menjalankan keyakinan agama masing-masing. Konsep toleransi dalam Islam sangat rasional dan praktis serta tidak berbelit-belit. ${ }^{8}$ Namun dalam hubungannya dengan keyakinan (akidah) dan ibadah, umat Islam tidak mengenal kata kompromi. Keyakinan umat Islam kepada Allah tidak sama dengan keyakinan para penganut agama lain terhadap tuhan-tuhan mereka. Demikian juga dengan tata cara ibadahnya. Bahkan Islam melarang penganutnya mencela Tuhan-Tuhan dalam agama manapun.

Dalam hidup antar umat beragama ada beberapa faktor yang mendorong terjadinya toleransi antar umat beragama yaitu :

a. Memperkuat dasar-dasar kerukunan internal dan antar umat beragama, serta antar umat beragama dengan pemerintah.

b. Membangun harmoni sosial dan persatuan nasional dalam bentuk upaya mendorong dan mengarahkan seluruh umat untuk hidup rukun dalam bingkai teologi dan implementasi dalam menciptakan kebersamaan dan sikap toleransi.

${ }^{8}$ Muhamad Agus Mushodiq, "Teori Identitas Dalam Pluralisme Agama Dan Identitas (Fenomena Pluralisme Dan Toleransi Beragama Desa Jrahi, Gunungwungkal, Pati, Jawa Tengah)," FIKRI : Jurnal Kajian Agama, Sosial Dan Budaya, 28 Desember 2017, 379-406, https://doi.org/10.25217/jf.v2i2.145. 
c. Menciptakan suasana kehidupan beragama yang kondusif dalam rangka memantapkan pendalaman dan penghayatan agama serta pengalaman agama yang mendukung bagi pembinaan kerukunan hidup intern dan antar umat beragama

d. Melakukan eksplorasi secara luas tentang pentingnya nilai-nilai kemanusiaan dari seluruh keyakinan plural umat manusia yang fungsinya dijadikan sebagai pedoman bersama dalam melaksanakan prinsip-prinsip berpolitik dan berinteraksi sosial satu sama lainya dengan memperlihatkan adanya sikap keteladanan. Dari sisi ini maka kita dapat mengambil hikmah bahwa nilainilai kemanusiaan itu selalu tidak formal akan mengantar nilai pluralitas kearah upaya selektifitas kualitas moral seseorang dalam komunitas masyarakat mulya (makromah), yakni komunitas warga memeliki kualitas ketaqwaan dan nila-nilai solidaritas sosial.

e. Melakukan pendalaman nilai-nilai spiritual yang implementatif bagi kemanusiaan yang mengarahkan kepada nilai-nilai ketuhanan, agar tidak terjadi penyimpangan-penyimpangan nilai-nilai sosial kemasyatakatan maupun sosial agama

f. Menempatkan cinta dan kasih dalam kehidupan umat beragama dengan cara menghilangkan rasa saling curiga terhadap pemeluk agama lain, sehingga akan tercipta suasana kerukunan yang manusiawi tanpa dipengaruhi oleh faktor-faktor tertentu

g. Menyadari bahwa perbedaan adalah suatu realita dalam kehidupan bermasyarakat, oleh sebab itu hendaknya hal ini dijadian mozaik yang dapat memperindah fenomena kehidupan beragama. 


\section{Kerukunan}

Kerukunan adalah istilah yang dipenuhi oleh muatan makana "baik" dan "damai". Hakikatya, hidup bersama dalam masyarakat dengan "kesatuan hati" dan bersepakat" untuk tidak menciptakan perselisihan dan pertengkaran (Depdikbud, 1985). Bila pemaknaan tersebutdijadikan pegangan, maka "kerukunan" adalah sesuatu yang ideal dan didambakan oleh masyarakat manusia. Kerukunan (dari ruku, bahasa Arab, artinya tiang atau tiang-tiang yang menopangrumah; penopang yang memberi kedamaian dan kesejahteraan kepada penghuninya) secara luas bermakna adanya suasana persaudaraan dan kebersamaan antar semua orangwalaupun mereka berbeda secara suku, agama, dan golongan.

kerukunan antar umat beragama merupakan pilar kerukunan nasional adalah sesuatu yang dinamis, karena itu haus dipelihara terus dari waktu ke waktu. Kerukunan hidup antar umat beragama sendiri berarti keadaan hubungan sesama umat beragama yang dilandasi toleransi, saling pengertian, menghargai kesetaraan dalam pengmalan ajaran agmanya dan kerja sama dalam kehidupan bermasyarakat, berbangsa, dan bernegara. Diartikan sebagai kehidupan bersama yang diwarnai oleh suasana baik dan damai, hidup rukun berarti tidak bertengkar, melainkan bersatu hati, dan sepakat dalam berfikir dan bertindak demi mewujudkan kesejahteraan bersama. Dalam kerukunan semua orang bisa hidup bersama tanpa kecurigaan, dimana tumbuh semangat dan sikap saling menghormati dan kesediaan untuk bekerja sama demi kepentingan bersama. Kerukunan atau hidup rukun adalah sikap yang berasal dari lubuk hati yang terdalam, terpancar dari kemauan untuk memang berinteraksi satu sama lain sebagai manusia tanpa tekanan dari pihak manapun. 


\section{Konflik}

Konflik yang terjadi pada komunitas keagamaan selama ini karena adanya kesalahpahaman atau kurangnya kesadaran beragama sehingga menyebabkan banyak terjadi konflik antar umat beragama. Sebagai contoh, kasus yang terjadi di Yogyakarta dimana terjadi ketegangan Warga Islam Pragolan dengan pendatang Kristen, dimana suasana pedesaan yang sebelumnya relatif kuat dengan kehadiran para pendatang Kristen secara bertahap mengalami perubahan layaknya suasana masyarakat perkotaan yang cenderung individualistik dan lebih banyak disibukkan oleh orientasi ekonomis daripada kehidupan sosial bermasyarakat. Konflik yang terjadi antar kelompok dan individu akan mengakibatkan potensi yang dapat menghantui ketertiban social yang dapat mengakibatkan integrasi Negara Kesatuan Republik Indonesia (NKRI).

Konflik berdarah yang terjadi di beberapa wilayah di Indonesia akhir-akhir ini, yaitu konflik antarumat beragama di Kuningan, Pandeglang, Tasikmalaya, Bekasi, dan Temanggung, menunjukkan pada kita semua, betapa rentannya masyarakat Indonesia jatuh dalam tindak kekerasan yang berujung pada perilaku anarkis. Hanya karena perbedaan keyakinan, seorang warga masyarakat rela menganiaya bahkan sampai menghilangkan nyawa sesama. Kondisi ini tentu menimbulkan pertanyaan di hati kita mengapa bangsa yang sejak lama telah dikenal sebagai bangsa yang ramah dan penuh toleransi mendadak berubah menjadi bangsa yang lebih mengedepankan kekuatan otot dibandingkan kekuatan otak untuk menyelesaikan persoalan yang dihadapinya. Perlu dicermati bahwa konflik sosial anarkis yang berlatar belakang perbedaan agama, budaya, dan atau keyakinan tidak pernah selesai dengan dialog, bahkan dalam dialog seringkali menyisakan berbagai potensi konflik, 
dominasi serta pembenaran oleh sekelompok yang merasa mayoritas sehingga kebenaran menjadi semu menurut kacamata mayoritas, dan kondisi inilah yang sering muncul dalam dialog, bukan solusi yang ada, tetapi melahirkan berbagai persoalan baru dan laten. Pemerintah saat ini, secara resmi hanya mengakui enam agama: Islam, Protestan, Katolik Roma, Hindu, Buddha, dan Konghucu. Meskipun bukan negara Islam, Indonesia adalah yang paling padat penduduknya di dunia yang mayoritas penduduknya muslim. Sebagian besar umat Hindu adalah Hindu Bali, dan sebagian besar umat Buddha di zaman modern Indonesia adalah etnis Cina. Meski sekarang agama minoritas, Hindu dan Buddha tetap menentukan pengaruh dalam kebudayaan Indonesia.

Konflik akan semakin mudah timbul bila interdependensi makin meningkat. Bila interaksi menjadi semakin kerap dan melibatkan berbagai kegiatan dan hal-hal yang semakin luas, peluang untuk munculnya ketidaksesuaian akan semakin besar.

Konflik antar umat beragama umumnya tidak murni disebabkan oleh faktor agama, melainkan oleh yang lainnya seperti faktor ekonomi, politik maupun sosial. Konflik ini tidak jarang terjadi karena persoalan pendirian rumah ibadah atau cara penyiaan agama yang tidak sesuai dengan ketentuan yang berlaku. Atau karena adanya salah paham di antara pemeluk agama. Konflik internal umat beragama terjadi karena adanya pemahaman yang diselewengkan atau pemahaman yang bebas semau sendiri tanpa mengikuti kaidah-kaidah yang ada. Minimnya pengetahuan masyarakat terhadap pluralisme melahirkan karakter apatis dan puritan terhadap toleransi beragama. 
132 Kharina, Danick, Arfan, Novry, Eny \& Farizky: Toleransi Antar...

\section{Hasil Penelitian dan Pembahasan}

\section{Kebebasan Beragama}

Pemahaman tentang kebebasan beragama pada masyarakat di Kecamatan Prambanan sangat perlu dilakukan agar tidak terjadi konflik, radikalisme (kekerasan) karena setiap pemeluk agama wajib menjamin kebebasan pemeluk agama lainnya untuk beribadah sesuai dengan agamanya masingmasing.

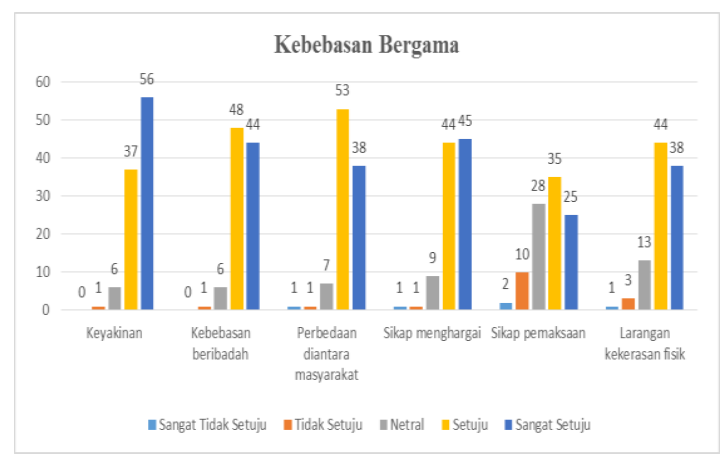

Gambar 2. Grafik Kebebasan Beragama

Gambar grafik 1 menunjukkan bahwa kebebasan beragama masyarakat di Kecamatan Prambanan tingkat persepsi dalam rentang sangat setuju adalah 25-56\% dengan tingkat presentase tertinggi adalah keyakinan dan persentase paling rendah adalah sikap pemaksaan hal tersebut ditandai bahawa masyarakat menyadari setiap individu mempunyai hak yang sama untuk memeluk agama sesuai keyakinannya asing-masing. Tingkat persepsi dalam rentang setuju adalah 35-53\% dengan tingkat persentase tertinggi adalah sikap menghargai agama lain dan persentase paling rendah adalah sikap pemaksaan. Tingkat persepsi dalam rentang netral adalah 6-28\% dengan tingkat persentase tertinggi adalah sikap pemaksaan dan persentase terendah adalah keyakinan. Tingkat persepsi dalam rentang tidak setuju adalah 1-10\% 
dengan persentase tertinggi adalah sikap pemaksaan dan persentase terendah adalah keyakinan, kebebasan beribadah dan perbedaan diantara masyarakat. Tingkat persepsi dalam rentang sangat tidak setuju adalah 1-2\% dengan persentase tertinggi adalah sikap pemaksaan dan yang lainya rendah.

Berdasarkan data yang diperoleh bahwa mayoritas responden memiliki persepsi tentang kebebasan beragama yang positif setuju dan sangat setuju sebesar $84,5 \%$ terhadap pernyataan-pernyataan yang diajukan terkait dengan toleransi antar umat beragama di Kecamatan Prambanan. Adanya kebebasan beragama, hal ini dapat dijelaskan dengan indicator keyakinan, kebebasan beribadah, perbedaan diantara masyarakat, sikap menghargai agama lain, sikap pemaksaan dan larangan kekerasan fisik (radikalisme) tercermin dengan tidak adanya perseteruan antar umat beragama namun saling bekerjasama dalam setiap hal.

\section{Kerukunan Beragama}

Kerukunan umat beragama di Kecamata Prambanan tidak luput dengan adanya para tokoh agama yang sudah menjalankan tugasnya dengan baik ataupun organisasiorganisasi keagamaan yang mampu menyatukan dan menjaga kerukunan umat beragama dan juga pemerintah yang sudah bekerjasama dengan baik.

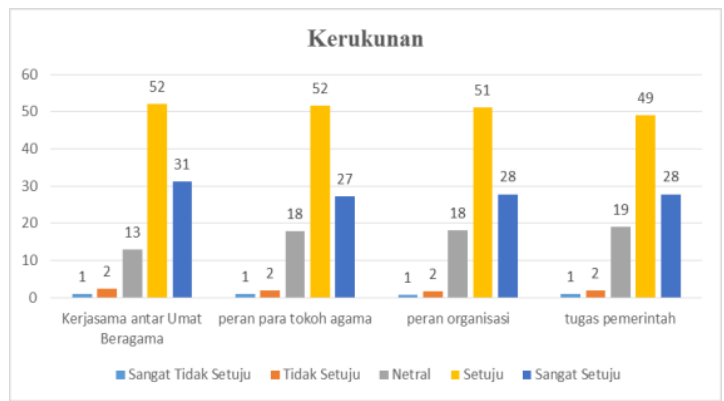

Gambar 3. Grafik Kerukunan Beragama 
Grafik 2 menunjukkan bahwa Masyarakat di Kecamatan Prambanan tingkat persepsi dalam rentang sangat setuju adalah $27-31 \%$ dengan persentase tertinggi adalah kerjasama antar umat beragama dan persentase terndah dalah peran para tokoh agama. Sedangkan tingkat persepsi dalam rentang setuju adalah 49-52\% dengan persentase tertinggi adalah kerjasama antar umat beragama dan peran para tokoh agama kemudian persentase terendah adalah tugas pemerintah. Tingkat persepsi masyarakat dalam rentang netral adalah 1319\%dengan persentase tertinggi adalah tugas pemerintah dan persentase terendah adalah kerjasama antar umat beragama kemudian tingkat persepsi masyarakat dalam rentang tidak setuju adalah $2 \%$ dengan persentase semua aspek tidak setuju dan dalam rentang sangat tidk setuju pun semuanya mempunyai persentase $1 \%$. Berdasarkan analisis diatas menujukkan bahwa masyarakat di Kecamatan Prambanan setuju dan sangat setuju dengan adanya kerukunan beragama, hal ini dapat dijelaskan dengan indicator kerjasama antar umat, peran para tokoh politik, peran organisasi dan tugas pemerntah mempunyai nilai persepsi sebesar 79,5\%. Sehingga menurut tabel dan grafik tersebut dapat dinyatakan bahwa masyarakat di Kecamatan Prambanan setuju dan sngat setuju dengan adanya krukunan beragama karena masayarakat prambanan memiliki tingkat kerukunan yang sangat tingi dan saling bekerjasama dengan antar umat beragama yang lainnya.

\section{Konflik Agama}

Masyarakat di Kecamatan Prambanan beranggapan bahwa konflik antar agama disebabkan karena adanya perselisihan, kepentingan politik, kepentingan ekonomi, buruknya radikalisme dan keegoisan maing-masing penganut. 
Hal itu merupakan sebuah doktrin justru semua agama itu mengajarkan kebaikan, menghargai orang lain dan toleransi

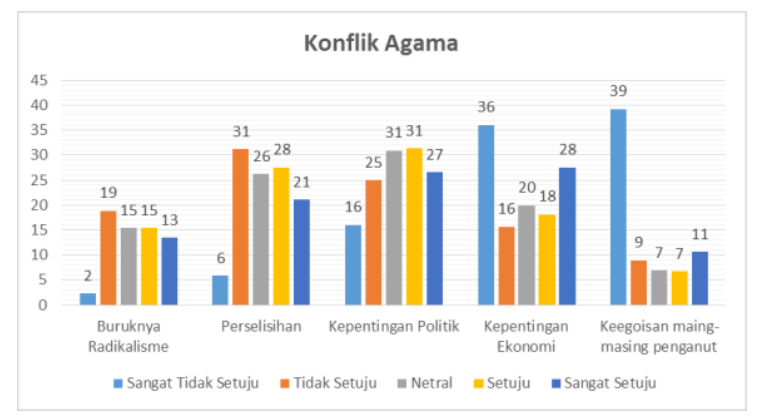

Gambar 4. Grafik Konflik Beragama

Grafik 3 di atas menunjukkan bahwa konflik agama pada masyarakat di Kecamatan Prambanan dalam rentang sangat setuju adalah 11-28\% dengan persentase tertinggi adalah kepentingan ekonomi dan persentase paling rendah adalah keegoisn masing-masing penganut, masyarakat Prambanan mempunyai persepsi bahwa konflik yang terjadi disebabkan karena adanya faktor ekonomi yang sangat berpengaruh dalam kehidupan sehari-hari. Tingkat persepsi masyarakat dalam rentang setuju adalah antara $7-31 \%$ dengan persentae tertinggi adalah kepentingan politk dan persentase terendah adalah keegoisan masing-masing penganut. Kemudian tingkat persepsi masyarakat dalam rentang netral adalah 7-31\% dengan persentase tertnggi adalah kepentingan politik dan persentase terendah adalah keegoisan masing-masing penganut. Tingakt persepsi dalam rentan tidak setuju adalah 9-31\% dengan persentase tertinggi adalah perselisihan dan persentase terendah adalah keegoisan masing-masing penganut. Tingkat persepsi masyarakat dalam rentang sangat tidak setuju adalah 2-39\% dengan persentase terendah adallah keegoisan masing-masing penganut dan persentase terendah adalah buruknya radikalisme bahwa masyarakat di 
Kecamatan Prambanan memilih netral dengan adanya konflik, hal ini dapat dijelaskan dengan indicator buruknya radikalisme, perselisihan, kepentingan politik, kepentingan ekonomi, keegoisan di masing- masing penganut sebesar $26 \%$.

Berdasarkan analisis tersebut menujukkan bahwa masyarakat di Kecamatan Prambanan memilih netral dengan adanya konflik, hal ini dapat dijelaskan dengan indikator buruknya radikalisme, perselisihan, kepentingan politik, kepentingan ekonomi, keegoisan di masing- masing penganut sebesar 26\%. Sehingga menurut grafik tersebut dapat dinyatakan bahwa masyarakat di Kecamatan Prambanan netral dengan adanya konflik di Kecamatan Prambanan. Masyarakat Prambanan lebih memilih tidak berpendapat terkait dengan adanya suatu konflik karena mereka tidak ingin ikut campur tangan hal tersebut. Jumlah tempat Peribaatan di Kecamatan Prambanan terdapat pada tabel dibawah ini.

\begin{tabular}{|l|c|c|c|c|c|}
\hline Kecamatan & Masjid & Mushola & Gereja & Pura/Vihara & $\begin{array}{c}\text { Klenten } \\
\mathrm{g}\end{array}$ \\
\hline Prambanan & 94 & 92 & 9 & 2 & - \\
\hline
\end{tabular}

Tabel 1: Persebaran Tempat Ibadah di Kecamatan Prambanan

Berdasarkan jumlah persebaran tempat ibadah di Kecamatan Prambanan dari 197 tempat peribadatan yang terdiri dari 94 masjid, 92 musholla, 9 gereja dan 2 vihara.

Persepsi adalah penilaian yang dalam hal ini terhadap kelompok agama lain, baik mengenai gambaran umumnya, masyarakatnya ataupun apa yang dilakukan oleh masyarakat agama lain bersangkutan. Konflik-konflik yang muncul antara pemeluk suatu agama dengan pemeluk agama lainnya bisa berasal dari adanya persepsi yang keliru atau doktrin pandangan jelek terhadap agama lain dan pemeluknya. 
Persepsi ini muncul setelah mereka melihat dan memberikan penilaian terhadap kelompok agama lain tersebut yang dianggapnya merugikan agama atau kelompok mereka. Dengan demikian pemahaman terhadap variabel ini menjadi penting mengingat hal ini akan memberikan gambaran kenapa hubungan sosial antar pemeluk agama memanas dan terjadi suatu konflik.

Kecamatan Prambanan sendiri mempunyai tingkat kerukunan dan toleransi yang cukup tinggi hal itu dapat dilihat pada grafik analisis toleransi dan kerukunan yang menunjukkan tingkat persepsi masyarakat Prambanan. Meskipun Kecamatan Prambanan terkenal dengan tempat peribadatan (Candi Prambanan) Hindu terbesar di Indonesia. Hal itu tidak menjadi suatu alasan untuk terjadinya konflikkonflik antar umat beragama masyarakat muslim maupun non muslim banyak yang memnfaatkan tempat peribadatan tersebut (Candi Prambanan) sebagai mata pencaharian seharihari.

Tindakan sosial atau sikap yang muncul, persepsi atau penilaian biasanya mendahului tindakan tersebut. Persepsi ini diukur dari sejumlah hal, antara lain: pemenuhan hak-hak keberagamaan, pemenuhan kewajiban dalam hubungan antarumat beragama, penilaian terhadap keberagaman, penilaian terhadap tindakan yang dilakukan oleh pemeluk agama yang berbeda, serta konflik yang berpeluang terjadi atau pernah dialami oleh responden dalam interaksinya dengan pemeluk agama lain. Berdasarkan data yang diperoleh, temuan bahwa mayoritas responden memiliki persepsi positif terhadap pernyataan-pernyataan yang diajukan terkait dengan toleransi antar umat beragama di Kecamatan Prambanan meskipun masyarakat menilai bahwa konflik yang trejadi dikarenakan adanya kepentingan politik dan ekonomi. 
Penelitian ini mendukung dari penelitian yang dilakukan oleh Rina Hermawati, 2016 terkait dengan toleransi antr umat beragama. Hasil penelitian tersebut menjelaskan bahwa masyarakat mempunyai sikap toleransi yang cukup tinggi saling menerima, saling menghormati dan saling terbuka terhadap agama lainnya. ${ }^{9}$

\section{Kesimpulan}

Masyarakat di sini hidup dalam sebuah perbedaan dan yang menjadi perbedaan mendasar pada masyarakat Kecamatan Prambanan adalah perbedaan agama pada masing-masing individunya. Di mana perbedaan tersebut tidak hanya terdapat pada masing-masing warganya melainkan perbedaan tersebut juga ada dalam satu keluarga. Satu hal yang perlu diketahui di sini adalah bahwa perbedaan yang ada pada masyarakat Kecamatan Prambanan tersebut tidaklah menjadikan mereka hidup dalam ketegangan hingga menimbulkan suatu konflik seperti konflik-konflik yang sering terjadi sekarang ini yang dilatarbelakangi oleh perbedaan agama, namun kehidupan mereka justru sangat harmonis, bisa hidup secara berdampingan, dan sangat menjunjung tinggi Toleransi dalam beragama. Yang mana pada setiap masyarakatnya bukan hanya mengakui keberadaan hak agama lain, tetapi juga terlibat dalam usaha memahami perbedaan dan persamaan dari setiap masingmasing penganut agama yang ada. Faktanya, bahwa setiap masyarakat yang berbeda agama tersebut dapat berinteraksi secara positif dalam lingkungan tersebut.

9 Hermawati, Rini. "Toleransi Antar Umat Beragama Di Bandung." Indonesian Journal of Anthropology, 2016. 
Hal seperti ini tentunya tidak terjadi secara alamiah atau datang dengan sendirinya. Jelas ada usaha-usaha yang mereka lakukan untuk mempertahankan kerukunan seperti itu. Dimana usaha-usaha tersebut mereka implementasikan dengan baik dalam kehidupan sehari-hari. Pola kerukunan umat beragama yang berkembang di 16 desa Kecamatan Prambanan ini sangatlah dinamik, hal ini dapat terlihat dari beberapa pola kerukunan yang berkembang di masyarakat, misalkan pola hubungan sosial keagamaan dan pola hubungan sosial kemasyarakatan. Selain itu ada juga beberapa faktor yang mempengaruhi terwujudnya kerukunan umat beragama di Kecamatan Prambanan, seperti ikatan kekeluargaan, saling menghormati dan menghargai antar umat beragama serta gotong royong yang telah menjadi budaya masyarakat di 16 desa Kecamatan Prambanan. Hal ini didasari adanya kebhinekaan tunggal ika yang menjadi semboyang bangsa Indonesia yang memilki arti berbeda beda tetap satu jua. Sehingga masyarakat di Kecamatan Prambanan Kabupaten Klaten memiliki tingkat kerukunan antar umat beragama yang tinggi.

\section{Daftar Pustaka}

Mushodiq, Muhamad Agus. "Teori Identitas Dalam Pluralisme Agama Dan Identitas (Fenomena Pluralisme Dan Toleransi Beragama Desa Jrahi, Gunungwungkal, Pati, Jawa Tengah)." FIKRI : Jurnal Kajian Agama, Sosial Dan Budaya, 28 Desember 2017, 379-406. https://doi.org/10.25217/jf.v2i2.145.

Aisyah BM. (2014). "Konflik Sosial Dalam Hubungan Antar

Umat Beragama". Dakwah Tabligh, Vol. 15 No. 2, Desember 2014.

Badan Pusat Statistik (BPS). Kecamatan Prambanan Dalam Angka 2017. 
140 Kharina, Danick, Arfan, Novry, Eny \& Farizky: Toleransi Antar...

Bukhori,B. (2012). "Toleransi Terhadap Umat Kristiani Ditinjau Dari Fundamentaliisme Agama Dan Kontrol Diri" (Studi pada Jamaah Majelis Taklim di Kota Semarang).

Burhanuddin, M. (2016). "Toleransi Antar Umat Beragama Islam Dan Tri Dharma”. Skripsi. Semarang Fakultas Ushuluddin dan Humaniora Universitas Islam Negeri Walisongo Semarang.

Hermawati, R. (2016). Toleransi Antar Umat Beragama Di Bandung. UMBARA : Indonesian Journal of Anthropology, Vol. 1 No. 2, Desember 2016.

Lestari, Bhineka Tunggal Ika: Khasanah Multikultural Indonesia di Tengah kehidupan Sara. Jurnal Pendidikan Pancasila dan Kewarganegaraan 2015

Muzzakir, Ahlan. (2015).'”Interaksi Sosial Masyarakat Islam

Dan Hindu Di Dusun Sumberwatu, Desa Sambirejo,

Kecamatan Prambanan Kabupaten Sleman Dalam

Mengembangkan Kerukunan”. Skripsi. Yogyakarta

Faklutas Ushuluddin dan Pemikir Islam Universitas Islam

Negeri Sunan Kalijaga Yogyakarta.

Nisa' (2016). " Kajian Kritis Tentang Toleransi Beragama

Dalam Islam”. Al Hikmah, Vol. 2 No 2, 2016.

Noupal,M (2017). "Paradigma Integralistik Dan Toleransi

Umat Beragama Di kota Palembang”. Intizar, Vol. 3 No 1,2017

Nurharyati, Indah. (2011). "Kerukunan Antar Umat (Studi kasus tentang perayaan hari besar umat beragam Islam dan agama Kong Hu Chu di kelurahan Kranggan Kecamatan Semarang Tengah Kota Semarang). Skripsi. Semarang Fakultas Ushuluddin dan Humaniora Universitas Islam Negeri Walisongo Semarang.

Prof. Dr. H. Hadi Sabari Yunus, M.A; DRS. 2015 "Metodologi Penelitian Wilayah Kontemporer". Yogyakarta: Pustaka Pelajar. 
Sugiyono. 2017. "Metode Penelitian Kuantitatif, Kualitatif, dan $R \& D$ ". Bandung: Alfabeta.

Sugiyono. 2015. "Statistika untuk Penelitian”. Bandung: Alfabeta.

Sujarweni, V.Wiratna. 2015. "SPSS untuk Penelitian”. Yogyakarta: Pustaka Baru Press.

Sumartias (2013). "Faktor-faktor Yang Mempengaruhi Konflik Sosial”. Penelitian Komunikasi, Vol. 16 No 1, Juli 2013.

Utoyo (2016). "Akar Masalah Konflik Keagamaan Di Indonesia”. Lex Librum, Vol 3 No 1, Desember 2016.

Yusuf, Angga. (2014). "Kerukunan Umat Beragama Antara Islam, Kristen Dan Sunda Wiwitan”. (Studi kasus: Kelurahan Cigugur Kecamatan Cigugur, Kunngan Jawa Barat). Skripsi. Jakarta Fakultas Tarbiyah dan Keguruan Universitas Islam Negeri Syarif Hidayatullah Jakarta. 
142 Kharina, Danick, Arfan, Novry, Eny \& Farizky: Toleransi Antar... 